\title{
Mummy was a fetus: motherhood and fetal ovarian transplantation
}

\author{
Jonathan M Berkowitz Mount Sinai Medical Center, New York, USA
}

\section{Abstract}

Infertility affects 15 per cent of the world's couples. Research at Edinburgh University has been directed at transplanting fetal ovarian tissue into infertile women, thus enabling them to bear children. Fetal ovary transplantation (FOT) has generated substantial controversy; in fact, one ethicist deemed the procedure 'so grotesque as to be unbelievable' (1).

Some have suggested that fetal eggs may harbour unknown chromosomal abnormalities: however, there is no evidence that these eggs possess a higher incidence of genetic anomaly than ova found in a healthy adult female. There is also concern that fetal egg children will be psychologically harmed by the knowledge of their special conceptual status. It will be demonstrated that special conceptual status in and of itself does not determine developmental success. Rather, psychological well-being is dependent upon how the family and child cope with the unique challenges inherent in FOT. Lastly, though considering FOT a legitimate method of family building, given the global population crisis the wisdom of procreational rights will be challenged. Inherent to this challenge is a re-evaluation of the treatment of infertility as a significant disease necessitating remedy.

'Who ran to help me when I fell, And would some pretty story tell, Or kiss the place to make it well?

My mother'

Ann Taylor, 'My Mother' (2)

\section{Introduction}

For most of us the word 'mother' is special. She is the person who gave birth to you, raised you, fed you, loved you, fought with you, and in the final analysis, did her best to be a good mother. For millions of years children, regardless of who raised

\section{Key words}

Infertility; fetal ovary transplantation (FOT); reproductive technologies; population; artificial and transplanted organs/tissues. them, could be certain they had a mother who with once a living person. However, the concept of motherhood has been challenged by research frqm Edinburgh University aimed at transplanting to ovaries of an aborted fetus into an infertile womag. Fetal ovary transplantation (FOT) will produce for the first time, a child who will inherit the genes ofa woman who herself never lived. For many these cof cumstances are most unsettling (3); a person whoge genetic mother was never born contradicts the way people have been born for millions of years.

Three important issues are raised by the adve@̊t. FOT. First, there is concern that by using fetals which have not been subject to environmeg pressure we may be introducing additional geñef anomalies into the population. It will be maintainfod in this paper that fetal eggs are not inferior and go not have a higher incidence of chromosomal abnotmality than eggs found in a healthy adult femafs. Furthermore, it will be asserted that it may be preferable to harvest fetal eggs as they have had lects exposure to environmental toxins, which are known to cause chromosomal aberrations.

Second, there are concerns about how a chtod might react to the knowledge that his mother was an aborted fetus. To this objection it will be demomstrated that anxiety over potential emotional damage is unwarranted in light of the significant analogoss history of children adopted in infancy and children produced via medically assisted conception (MAG. And lastly, it will be maintained that while FOT isa legitimate method of family building, the development of procedures to introduce additional children into an already over-populated world may not becon society's best interest.

\section{Genetic objections}

Concern exists over using fetal eggs which 'have nipt been subjected to the pressures which govfon survival and normal development to adulthood' ( $($ ): in that it is possible fetal eggs may harbour gene anomalies not eliminated through natural selection. However, both our current knowledge of oogenesis (5), and studies on human and non-human subjects 
contradict much of this concern. In fact, this lack of environmental exposure may be preferable, given the established association between advanced material age and increased risk of congenital malformation (6).

By the fifth month of gestation the average female fetus will have approximately 7,000,000 eggs, 400,000 of which will remain at puberty with less than 500 of these being ovulated (7). Some may argue that we should avoid using fetal eggs since we are selecting eggs which have not been 'subject to pressures' which allow specific eggs to survive to ovulation. The actual mechanisms behind why some eggs survive to menarche are not known (8); however, there is no evidence to suggest that a particular egg survives because it is superior to other eggs. This also applies to ovulation where up to 15 follicles (9) mature simultaneously yet only one will ultimately ovulate (10). This process is controlled by subtle temporal hormonal interactions and once again there is no evidence to suggest that the eggs are subject to selective pressure (11).

\section{Experiments}

Besides the lack of evidence that fetal eggs are genetically inferior, the contention that fetal eggs are not subject to environmental pressure is not entirely true. For fetal eggs to mature they must be stimulated by the recipient's maternal hormones. What distinguishes fetal eggs is the temporality of exposure. Fetal tissue grafted into a post-pubescent woman has minimal exposure to a pre-pubescent hormonal environment and significantly less exposure to the post-pubescent hormonal environment. There is no evidence that genetic defect results from a temporal reduction of maternal hormonal exposure. In fact, experiments on both human and non-human subjects indicate ovarian tissue transfer is both a viable and safe procedure. In 1945 embryonic mouse ovarian tissue was grafted into mature mice which successfully produced young (12). Human births have already been reported using immature eggs harvested from one patient and fertilized via in vitro fertilization (IVF) in another patient who 'delivered healthy triplet girls' (13). Four additional children have been born using this procedure and to this date, they are all 'very healthy' with 'no linked genetic anomaly' (14).

Contrary to concerns over the lack of environmental pressure on transplanted fetal eggs, it may be preferable that fetal eggs have minimal environmental exposure. It is postulated that the association between advanced material age and an increased incidence of birth defects (15) is that; in addition to 'genetic factors' (16), the eggs, having existed longer, suffer more environmental insults (17). While only 10 per cent of congenital defects can be directly attributed to 'environmental factors', the aetiology of approximately 65 per cent of all congenital defects is not clear and may represent a combination of both genetic and environmental insults (18). Though teratogenesis concerns post-conceptive insults, it is conceivable that environment similarly affects the unfertilized, preconceptive egg (19). In fact, there are a number of congenital defects, including Down's Syndrome (20), which result from pre-conceptive non-disjunction (21). What role environment plays in these preconceptive anomalies remains to be determined; however, 'it has been known for a long time that the likelihood of non-disjunction occurring increases with advancing maternal age' (22). Given this association between advanced maternal age and non-disjunction, one can argue that fetal eggs may harbour fewer genetic anomalies, because they have had less potentially damaging environmental exposure.

Another argument advanced against FOT is that we are skipping a generation of evolution and thus 'breaking a natural law of biology' (4). This is a weak argument as it fails to take into consideration the molecular basis of evolution. Evolution occurs when re-combined or mutated genetic material is passed from one generation to the next at conception (24). The genetic material in a fetal egg has already undergone re-combination and is arrested in an early stage of cell division till ovulation (24). At ovulation, which for some eggs may not occur for forty years, the ovum completes nuclear division and it is not till conception that a unique genome (25) is created. It is important to remember that evolution can only occur if genetic material is passed on to progeny. If a fetus is aborted, it can never contribute to our evolutionary heritage as its unique genes are lost forever unless, of course, fetal ova are harvested and grafted into a live reproducing woman. Therefore, concerns about 'skipping a generation' are totally unfounded as abortion (ie, the death of the organism prior to procreation), represents an evolutionary dead end.

\section{Chromosomal defects}

Another objection to the use of FOT is that spontaneously aborted fetuses have a high incidence of chromosomal defect. This is a valid concern because miscarriage is frequently secondary to genetic anomaly (26). However, one could meet this objection, at least in part, by pointing out that it is possible to examine chromosomes for both gross and subtle genetic defects, thus enabling physicians to screen potential donor eggs for chromosomal defect(s).

If our ability to detect genetic abnormalities in spontaneously aborted fetal tissue is not satisfactory, we can limit the harvesting of ovarian tissue to elective abortions where there is a lower risk of chromosomal abnormality. Nevertheless, no matter how conception is achieved, be it 'natural' or medically assisted, there will always be a risk of unknowingly 
passing on a genetic defect. It may be asking too much of medicine to detect every chromosomal abnormality; however, present and future genetic analytic techniques should enable physicians significantly to reduce the incidence of birth defects.

Lastly, some fear that increased demand for fetal tissue secondary to infertility treatment will 'encourage abortion' (4). It is, however, questionable how many women would undergo this invasive (27) and psychologically complicated (28) procedure purely for the benefit of another woman. In fact, it has been argued that abortion for the purpose of harvesting fetal tissue is morally reprehensible as it shows a gross disregard for life. While there is extensive debate over whether or not a fetus represents 'human' life, there is little doubt a fetus represents a form of life which has the potential to become human. To prevent such abuse, legislation could be enacted prohibiting reimbursement for donated fetal tissue. There were approximately 58,000 abortions performed in the United States during 1988 (29). Millions of eggs could be obtained even if consent for fetal tissue donation were granted in only a small percentage of abortions.

\section{Emotional repercussions for fetal mothers}

For most individuals, the woman who raised them is the same person who sweated in labour to give birth to them. That a child can be conceived from the egg of a female who never lived outside her own mother's womb is an idea so alien to ancient traditions that it demands scrutiny - an idea one Boston University ethicist claimed to be 'so grotesque as to be unbelievable' (1). While the moral outrage of some is expected, given the uniqueness of FOT, history offers ample precedent for similar genealogical circumstances.

Children raised by adults other than their 'biological' parents have undoubtedly existed during most if not all of human history. Take, for instance, the familiar scenario of a child adopted in infancy who has no personal memory of her biological parents and, as has been standard practice in the past (30), will know little if anything about them. An objection raised against FOT is the potential reaction of progeny to the news that their genetic mother was an aborted fetus. This argument is flawed as it assumes children carry the cultural and intellectual baggage of adults. We are at intellectual and emotional ease with the ideas and technology to which we are born. Tension is created by the introduction of new ideas and technology which upset established norms (31). For example, that this paper was written on a lap-top computer is mind-boggling to my mother while for my son who has been raised computer-savvy, this fact hardly deserves notice. Most will agree that children are not born with preconceived notions of morality; rather, a child's moral character results from interactions with significant others (32). Therefor for the fetal egg child (FEC) to accept his speciat circumstances with minimal emotional trauma two conditions should be met. First, the FEC must accepted by her family and significant others. Secon $\mathscr{H}_{\text {, }}$ the facts behind the child's non-traditional conceptugl status should be disclosed in a 'well-timed ar: developmentally appropriate' (33) manner. Wi these conditions met, the child's chances of acceptirg his special circumstances without significant difficulte are enhanced. This is not to imply there will be ne negative reaction once a child learns of her special conceptual status. Certainly there may be mansy emotions associated with the knowledge of beig conceived outside sexual intercourse (34). Studies 涖 children produced through MAC have demonstrated both positive and negative associations. An Australiag group reported no increase in psychosocial problenis above that which might be expected in the population at large' in a series of IVF children between the ages one and three (35). Another study concluded that 'the majority [of children produced via IVF] were pe? forming above the norm for their chronological age but were subject to 'a significantly higher inciden of ... behavioral and emotional problems' (36) Compare this to the testimonial offered by Lillia Atallah, a 'test tube baby', when she said: 'Knosging about my AID (Artificial Insemination by Domog) origin did nothing to alter my feelings for my faril Instead, I felt grateful for the trouble they had taken give me life' (37).

In addition to studies on children produced through MAC, there is a substantial history $\vec{g} f$ adopted (or orphaned) children who, like a potential FEC, never knew or have no memory of their genet mother. Controversy exists, however, concerning the incidence of psychiatric disturbance within adoptive families (38). There is an extensive literatume supporting the contention that adopted childre display no significant psychological harm as a resưt of being adopted (39). A study published by the Child Welfare League of America in 1970 concluded that adopted children exhibit 'no evidence of mone pathology than the control children ... living wi their natural parents (40). In fact Marvin Eisensta釆 has even suggested there exists an occasional positige correlation between being orphaned and achieviement (41). Being myself adopted, I can say with co fidence that the knowledge that those who raised rfie were not my biological parents was inconsequentiơ. My real parents are the mother and father who raised me, not my biological parents. Nevertheless, I agreg with Miriam Reitz when she wrote 'adoption is a second-best plan' when compared to children being raised by their natural parents (42). Marriage and child-rearing can be difficult and it is not inconcei able that adoption complicates these experiences. Countering literature which may minimize tife problems inherent in adoption is ample evidence suggesting that adoption can be difficult both for the 
adoptee and the adoptive parents (43). Among the important issues adoptive parents must face are infertility (44) and the lack of biological connection to their child (45). Adopted children are similarly challenged, having to confront issues of abandonment (46), separation, and feelings of being different (47).

Given the inherent complexity of interpersonal adoptive/MAC relationships, we may expect continued controversy. What we can learn from the many conflicting studies is that adoption/MAC success is dependent on how parents and children adapt to their particular circumstances. Adoptive/ MAC parents, though faced with special challenges, are inherently no better or worse than biological parents. Adoption and MAC have certainly not been dismal failures. With respect to adoption, the persistence of this ancient practice is a testimony to its utility. Besides placing children in what are ideally nurturing homes, adoption and MAC offer infertile couples the opportunity to experience all the good (48) we associate with parenthood. It is for these vital human reasons that adoption and MAC, despite potential pitfalls, have remained, and will remain, viable and positive alternatives for family building.

While adoption and MAC-created families may have an increased risk of dysfunction, their potential shortcomings certainly do not warrant avoiding the joy of parenthood. Fetal egg children will be similar in many ways to children who are adopted or created through MAC. While adoption and MAC are not without hazard, what seems clear is that these alternatives to family building are, in and of themselves, not detrimental to the child or the family. Rather, it is the family's 'ability to deal with the special challenges inherent in adoptive [or MAC] relationships' which ultimately determines outcome (49). Successful child development is dependent more upon the quality of parenting than the genealogical ties a child has with her parents (50). Given these considerations, concerns over the possible psychological ramifications of being a FEC are perhaps exaggerated.

Lastly, some have suggested that we can avoid all potential harm by keeping the child ignorant of its conceptual history (51). Though a discussion concerning 'right to know' theories is beyond the scope of this paper, given how bad human beings are at keeping secrets, honesty is indeed the best policy (52). Better this child know his special circumstances at an early age 'so the knowledge can be absorbed over a period of time as the child grows' (53). 'Children and adults are less upset by what are presumed to be unpalatable facts than by the deception that is designed to protect them from the facts' (54).

\section{Issues of population control}

'and God said unto them, Be fruitful, and multiply, and replenish the earth.'

Genesis 1:28 (55)
Procreation is so basic to the human condition and satisfies so many personal and cultural needs that it occupies a unique position in both our legal and psychic heritage. However, considering the global population crisis (56), one may ask why we continue to devise new ways of combating infertility and thus, produce more children. Is it in society's best interest to afford each individual a right to procreate?

Most cultures have recognized a right, if not an obligation (57) to procreate. For instance, according to the Code of Jewish Law it is the duty of every man to take a wife to himself, in order to fulfil the precept of propagation' (58). In addition to religious dictates, the American judiciary has clearly recognized a right to procreate (59). Given the primacy of procreation, it is not surprising that infertility is considered a 'disease' necessitating treatment (60). Webster's Third New International Dictionary defines disease as, 'an impairment of the normal state of the living animal ... or any of its components that interrupts or modifies the performance of the vital functions' (61).

As most couples are fertile (62), infertility may be viewed as an impairment of the normal state. Additionally, propagation can be considered a vital function as it preserves the species and satisfies many cultural and personal needs. Though admittedly a disease, does infertility endanger the life of the individual? Certainly no one has ever died from this malady and though not life-threatening, infertility is not without negative psychological consequences (63). Infertility does adversely affect an individual's quality of life and it is for this reason we treat infertility as a medical disease.

While it may benefit infertile couples to become parents, it is not in society's best interest that all couples have children. Does the reduction of psychological distress warrant the introduction of additional children into an already over-populated world? This question is related to the larger issue of applying medical technology to human disability. Few would argue against using medicine to combat, if not eradicate, cancer. More controversial is the use of human growth hormone to enhance a normal child's height. Infertility falls between these two extremes: it is not a life-threatening illness yet nor is it frivolous.

Treating infertility represents a balance between the needs of the individual versus those of society. As long as we assume there is a right to procreate we must grant each infertile couple the opportunity to have children. However, if we agree there is a population crisis then assuming that each individual has a right to procreate is certainly not going to be in the best interest of society.

\section{Conclusions}

Our present knowledge of reproduction dispels much of the concern over introducing unforeseen 
chromosomal defects through FOT. There is no medical evidence which suggests that fetal ovaries or eggs are inferior to the eggs present in a healthy adult female. With the exception of heritable disease, it is irrelevant who the genetic or biological mother of a child is. In the case of adopted children, who are analogous to potential FEC, there is ample evidence in the literature that adoption in and of itself is not detrimental. Rather, the dysfunction observed in some families results from the dynamics of the family situation, not the adoption. Furthermore, given the success of adoption and the similarities of adopted children to FEC, one can reasonably conclude that concerns of psychological harm resulting from a child knowing his genetic mother was an aborted fetus are overestimated. Adopted children, like potential FEC, rarely known anything about their genetic parents and are raised by individuals who are genetically unrelated. While adoption may not be the ideal, it is reiterated that the persistence of this ancient practice illustrates its utility.

Much of the resistance to FOT stems from the procedure's novelty. Throughout the twentieth century many of our ideas as to what is possible and hence normal have been shattered. Think of the computer user, fifteen years ago; his $64 \mathrm{~KB}$ monster sitting mightily on the desk, confronted by the 33 $\mathrm{MHz}, 200 \mathrm{MB}$ lap-top. Remember the uproar (64) in 1978 with the birth of Louise Brown, the world's first 'test tube baby'. It is not hard to envision that once established, FOT and FEC will be one of many variations of MAC and will gain a well deserved 'measure of respectability' (65).

It is important to challenge the assumption of a right to procreate. We should be asking why, in a world which is increasingly populated, we continue to devise new means of introducing children. Should we use science to resolve all of nature's imperfections? Is infertility an 'imperfection' needing remedy? Is a fetus an ethically and legally legitimate source for eggs, ovaries, and other tissues? If we accept the premise that there exists a fundamental right to procreate, then the ovaries of aborted fetuses procured by the most rigorous medical, ethical, and legal standards are a viable and morally justifiable source of potential personhood.

fonathan $M$ Berkowitz, $M D$, is a pathologist at the Mount Sinai Medical Center, New York, USA.

\section{References and notes}

(1) Kolata G. Fetal ovary transplant is envisioned. The New York Times 1994 Jan 6: A16.

(2) Taylor A. In: Kaplan J, general editor. Bartlett's familiar quotations. Boston: Little, Brown and company, 1992: 394.

(3) See reference (1): (cols 4-6).

(4) Human Fertilisation and Embryology Authority: Public consultation document. Donated ovarian tissue in embryo research and assisted conception. Londq HFEA, 1994: 6.

(5) Oogenesis is the process by which ova (eggs) devel within the ovaries.

(6) Stocker J T, Dehner L P, eds. Pediatric patholo Philadelphia: J B Lippincott Company, 1992: 41-7才त.

(7) Sadler T W. Langman's medical embryology. Londog: Williams and Wilkins, 1990: 10-11.

(8) Scott J R, Disala P J, Hammond C B, Spella W N, eds. Danforth's obstetrics and gynecolo Philadelphia: J B Lippincott Company, 1994: 13. ఝँ

(9) A follicle is a collection of cells consisting of a centrally located oocyte (egg) surrounded by supporting cells.

(10) See reference (7): 11 .

(11) Sjöberg N O, et al. Local regulation of ovarian functious. Park Ridge, New Jersey: The Parthenon Publishiæg Group, 1992: 21-96. See also Findlay J K. Molecu占 biology of the female reproductive system. New Yofl: Academic Press, 1994: 101-127.

(12) Russell W I, Patricia M, Douglass P M. Offspring from unborn mother. Proceedings of the Nationeol Academy of Sciences, USA 1945; 31: 402-404.

(13) Kwang Yul Cha, et al. Pregnancy after in vitro fertilization of human follicular oocyte collected from nonstimulated cycles. Their culture in vitro and their transfer in a donor oocyte program. Fertility and stere ity 1991; 55: 109-113.

(14) Letter to author, from Kwang Yul Cha, V President of Cha Hospital, Infertility Medical Centê, Seoul, Korea, 1994: Nov 29.

(15) Hook E B. Rates of chromosome abnormalities axdig ferent maternal ages. Obstetrics and gynecology 9 58: 282-285. See also Hook E B, et al. Chromosơng abnormality rates at amniocentesis and in live-bogn infants. Fournal of the American Medical Association 1983; 249: 2034-2038.

(16) Verma R S. The genome. New York: VCH Publish $\overrightarrow{\overrightarrow{\text { Pas }}}$ Inc, 1990: 216-217.

(17) Parry J P, Sors A. The detection and assessment $\underset{\mathrm{f}}{\mathrm{f}}$ the aneugenic potential of environmental chemicals: the European Community aneuploidy projest. Mutation research 1993; 287: 3-15. See also Oshimữa M, Barrett J C. Chemically induced aneuploidy mammalian cells: mechanisms and biological signifcance in cancer. Environmental mutagenesis 1986; \&: 129-159. Watanabe T, Endo A. Chromosone analysis of preimplantation embryos after cadmium treatment of oocytes at meiosis I. Environmental mutagenesis 1982; 4: 563-567. Vehida I A, Curtis E J. possible association between maternal radiation and Mongolism. Lancet 1961; 2: 848-850.

(18) O'Rahilly R, Müller F. Human embryology and teraẗ ogy. New York: Wiley-Liss, 1992: 70. See also Sadier $T$ W. Langman's medical embryology. Londow: Williams and Wilkins, 1990: 116.

(19) Uchida I A, et al. Material radiation and chromo\$mal aberrations. Lancet 1968; 2: 1045-1049. See a Sbrana I. C mitosis and numerical chromosomes aberration analysis in human lymphocytes: 10 known or suspected spindle poisons. Mutation research 199 ; 287: 57-70. Carr D H. Chromosome studies selected spontaneous abortions: conception after o\&्l contraceptives. The Canadian Medical Association journal 1970; 103: 343-348.

(20) Gardner R J M, Sutherland G R. Chromosome abnormalities and genetic counselling. Oxford: Oxford University Press, 1989: 13-16. 
(21) Nondisjunction in the unequal distribution of chromosomes between developing sperm and ova.

(22) See reference (20): 14.

(23) Lewontin R C. The genetic basis of evolutionary change. New York: Columbia University Press, 1974: 3-6.

(24) Sadler T W. Langman's medical embryology. London: Williams and Wilkins, 1990: 5-12.

(25) A genome represents the entire genetic complement of an individual.

(26) See reference (6): 41.

(27) See reference (8): 638

(28) Stotland N L, ed. Psychiatric aspects of abortion. Washington, DC: American Psychiatric Press Inc, 1991: 17-37. See also Woods Jr J R, Esposito J L, eds. Pregnancy loss: medical therapeutics and practical considerations. Baltimore: Williams and Wilkins, 1987: 38-41.

(29) US Department of Commerce. Economics and Statistics Administration. Bureau of the Census. Statistical abstract of the United States 1993 [113th ed]. Washington: US Department of Commerce, 1993: 83.

(30) Bartholet E. Family bonds: adoption and the politics of parenting. New York: Houghton Mifflin Company, 1993: 51-61. See also DeWoody M. Adoption and disclosure of medical and social history: a review of the law. Child welfare 1993; 77: 195-218.

(31) Toffler A. Future shock. New York: Random House, 1970: 305-326.

(32) Lewis M. Child and adolescent psychiatry: a comprehensive textbook. Baltimore: Williams and Wilkins, 1991: 187-94.

(33) Pruett K D. Strange bedfellows? Reproductive technology and child development. Infant mental health journal 1992; 13: 312.

(34) Blyth E. Assisted reproduction: what's in it for children? Children and society 1990; 4: 167-182.

(35) Mushin D N, Barreda-Hanson M C, Spensley J C. In vitro fertilization children: early psychosocial development. Fournal of in vitro fertilization and embryo transfer 1986; 3: 247-252. See also Yovich J F, et al. Developmental assessment of twenty in vitro fertilization (IVF) infants at their first birthday. fournal of in vitro fertilization and embryo transfer 1986; 3 : 253-257.

(36) Golombok S, Bhanji F, Rutherford T, Winston R. Psychological development of children of the new reproductive technologies: issues and a pilot study of children conceived by IVF. Fournal of reproductive and infant psychology 1990; 8: 42.

(37) Atallah L. Report from a test-tube baby. The New York Times magazine 1976; Apr 18: 48.

(38) Wolkind S. Psychological development of the adopted child. In: Wolkind S, ed. Clinics in developmental medicine, no 74: medical aspects of adoption and foster care. Philadelphia: J B Lippincott Company, 1979: 67-73.

(39) Watkins M, Fisher S. Talking with young children about adoption. New Haven: Yale University Press, 1993: 25-56. See also Bohman M, Sigvardsson S. Outcome in adoption: lessons from longitudinal studies. In: Brodzinsky D M, Marshall D, Schechter M D, eds. The psychology of adoption. New York: Oxford University Press, 1990: 93-106.

(40) Lawder E A, et al. A followup study of adoptions. New York: Child Welfare League of America, 1970; 2: 73. See also Tizard B. Adoption: a second chance. New York: The Free Press, 1977.

(41) Eisenstadt M, Haynal A, Rentchnick P. Parental loss and achievement. Madison, CT: International Universities Press Inc, 1989: 3-33.

(42) Reitz M, Watson K W. Adoption and the family system. New York: The Guilford Press, 1992: 4.

(43) For an exhaustive examination of many of the problems faced by adopted children and their parents see Reitz M, Watson K M. Adoption and the family system. New York: The Guilford Press, 1992 and Ansfield J G. The adopted child. Springfield, IL: Charles C Thomas, 1971: 18-34.

(44) See reference (42): 95-116.

(45) Bax M, Hart H, Jenkins S M. Child development and child health: the preschool years. Oxford: Blackwell Scientific Publications, 1990: 160.

(46) Schucker E. Psychological effects of the new reproductive technologies. In: Embryos, ethics, and women's rights: exploring the new reproductive technologies. New York: Harrington Park Press, 1988: 142.

(47) Sokolff B Z. Alternative methods of reproduction. Clinical pediatrics 1987; 26: 15.

(48) Aristotle. Nicomachean ethics: 8:12.

(49) Rosenberg E B. The adoption life cycle: the children and their families through the years. New York: Free Press, 1992: 87.

(50) See reference (46): 143-144. However, for those who insist on emphasizing parent and child relatedness, FOT can be viewed as superior to adoption and many instances of MAC in that most FEC will be raised by both their biological mother and genetic father.

(51) Ansfield J G. The adopted child. Springfield, IL: Charles C Thomas, 1971: 35-36.

(52) See reference (33): 312-318. See also Brandon J. Telling the AID child. Adoption and fostering 1979; 95: 13-14.

(53) New South Wales Infertility Social Workers' Group. Donor insemination: do we tell our child? New South Wales Infertility Social Workers' Group, Australia.

(54) Clamar A. Psychological implications of the anonymous pregnancy. In: Offerman-Zuckerberg $\mathrm{J}$, ed. Gender in transition: a new frontier. New York: Plenum Medical Book Company, 1989: 118.

(55) The Bible. Genesis 1: 28.

(56) Borrie W D. The growth and control of world population. London: Weidenfeld and Nicolson, 1970: 268-98. See also Loraine J A. Sex and the population crisis: an endocrinologist's view of the 20th century. St Louis: The C V Mosby Company, 1970: 104-127. Willing M. Beyond conception: our children's children. Boston: Gambit Incorporated, 1971: 39-47.

(57) Pope Paul VI. On the regulation of birth [encyclical letter 1968: Jul 29]. Boston: St Paul Editions, 1968: 7. See also Smith J E. Humanae vitae: $A$ generation later. Washington, DC: The Catholic University of America Press, 1991: 42-54.

(58) Ganzfried S. Code of fewish law, vol 4. New York: Hebrew Publishing Company, 1963: 6.

(59) Procreational liberty is rooted in constitutional protections of privacy. See Skinner v Oklahoma, 316 US 535 (1942). See also: Meyer v Nebraska, 262 US 390, 399 (1923), Stanley $v$ Illinois, 405 US 645, 651 (1972); Robertson J A. Embryos, families, and procreative liberty: the legal structure of the new reproduction. Southern California Law review 1986; 59: 942-1041; Robertson J A. Procreative liberty and the control of conception, pregnancy, and childbirth. Virginia law review 1983; 69: 405-464; Robertson J A. Procreative liberty and the state's burden of 
proof in regulating noncoital reproduction. Law, medicine and health care 1988; 16: 18-26; Ikemoto L C. Providing protection for collaborative, noncoital reproduction: the right of intimate association. Rutgers law review 1988; 40: 1273-1309. For comment on preceding article see: Prohibiting payments to surrogate mothers: love's labor lost and the constitutional right of privacy. Fohn Marshall law review 1987; 20: 715-741.

(60) Buttram Jr V C, Reiter R C. Surgical treatment of the infertile female. Baltimore: Williams and Wilkins, 1985: 289-333.

(61) Grove P B, editor-in-chief. Webster's third new inter- national dictionary of the English language unabridgfd. Springfield, MA: G and C Merriam Company, 1946: 648.

(62) Hafez E S E. Assisted human reproductive technology. New York: Hemisphere Publishing Company, $19 \overline{\mathrm{A}} 1$ : 93.

(63) Stotland N L, ed. Psychiatric aspects of reproductive technology. Washington: American Psychiatric Prझs, 1990: 124-125.

(64) Bonnicksen A J. In vitro fertilization: building poncy from laboratories to legislatures. New York: Columbia University Press, 1989: 12-24.

(65) See reference (64): 19. 
donors. A legal comment. British Medical fournal 1995; 310: 718.

17 McLean SAM. Making advance medical decisions. Fournal of the Medical and Dental Defence Union 1995; 11: 28-9.

$18 \operatorname{Re} \mathrm{C}$ (adult refusal of medical treatment) [1994] 1 All ER 819.

19 British Paediatric Association. Guidelines for the ethical conduct of medical research involving children. London:
British Paediatric Association, 1992.

20 Royal College of Physicians of London. Research involving patients. London: Royal College of Physicians of London, 1990.

21 Royal College of Psychiatrists. Guidelines for research ethics committees. Psychiatric Bulletin 1990; 14: 48-61.

22 Law Commission Report 231. London: Law Commission, 1995.

\section{Correction}

In the paper, "Mummy was a fetus: motherhood and fetal ovarian transplantation", 1995; 21 : 298-304, the number of abortions in the United States for 1988 was given as 58,192 . The correct number of abortions in the United States for that year is 1.59 million. 